\title{
Analysis of Bakery Sewage Treatment Process Options Based on COD Fraction Changes
}

\author{
Joanna Struk-Sokolowska', Justyna Tkaczuk ${ }^{1}$ \\ ${ }^{1}$ Bialystok University of Technology, Faculty of Civil and Environmental Engineering, Department of Techno- \\ logy and Systems in Environmental Engineering, ul. Wiejska 45E, 15-351 Bialystok, Poland \\ * Corresponding author's e-mail: j.struk@pb.edu.pl
}

\begin{abstract}
Municipal WWTPs often receive industrial wastewater including the bakery sewage. The effluent of the bakery industry has a high biological oxygen demand (BOD). In addition to high BOD, this wastewater contains high chemical oxygen demand (COD), total Kjeldahl nitrogen (TKN) and is characterized by a dark color. The effect of bakery wastewater contribution on the COD fraction changes in the municipal sewage is presented in this paper. The study was conducted in July 2016 in a WWTP located in Lipsk, East-North Poland. The sewage receiver is the Biebrza River. The volume contribution of bakery wastewater is $10 \%$. The analytical results were used to compute the percentage value contribution of individual COD fractions in wastewater. During the study, the following fractions were identified: $\mathrm{S}_{\mathrm{S}}-\mathrm{COD}$ of readily-biodegradable dissolved organic matter, $\mathrm{S}_{\mathrm{I}}-\mathrm{COD}$ of non-biodegradable dissolved organic matter, $\mathrm{X}_{\mathrm{S}}-\mathrm{COD}$ of slowly-biodegradable non-soluble organic matter, $\mathrm{X}_{\mathrm{I}}-\mathrm{COD}$ of non-biodegradable non-soluble organic matter. The method used for the COD fraction determination in wastewater was developed based on the ATV 131P guidelines (ATV-DVWK-A131P). The aim of the study was to determine the effect of bakery wastewater contribution on the COD fraction changes during the technical scale biological wastewater treatment with an activated-sludge process. The percentage contributions of individual COD fractions in wastewater were compared with the shares in the wastewater from other food industries (dairy, olive mill, tomato, sugar beet, potato processing, winery). In raw wastewater, the $X_{\mathrm{S}}$ fraction was dominant $44.2 \%$. $\mathrm{S}_{\mathrm{S}}$ fraction was $38.8 \%$. In raw wastewater, the $\mathrm{S}_{\mathrm{I}}, \mathrm{X}_{\mathrm{I}}$ fractions ranged from 2.3 to $14.8 \%$. In the effluent the $\mathrm{S}_{\mathrm{S}}$ fraction was not noted, which is indicative of microorganisms consumption. The WWTP effluents mostly $(43.4 \%)$ contained slowly-biodegradable non-soluble organic matter $\left(\mathrm{X}_{\mathrm{S}}\right)$. Non-biodegradable dissolved organic matter ( $\mathrm{S}_{\mathrm{I}}$ fraction) had a high share of $42.3 \%$.
\end{abstract}

Keywords: wastewater, municipal, bakery, food industry, COD fractions, activated sludge process

\section{INTRODUCTION}

Industrial pollution is still a major concern for sewage treatment and despite its significance, sound and systematic pollution control efforts are very poorly documented. The character and treatability of the industrial wastewater is highly variable and specific for each industrial activity. The issues related to the activated sludge treatment, such as biodegradability based characterization, modeling, assessment of stoichiometric and kinetic parameters and design, as well as the issues of industrial pollution control are not completely solved [Orhon et al. 2009]. The bakery industry is one of the world's major food industries and varies widely in terms of production scale and process. Traditionally, bakery products may be categorized as bread and bread roll products, pastry products (e.g., pies and pasties), and specialty products (e.g., cake, biscuits, donuts, and specialty breads). Flour, yeast, salt, water and oil/fat are the basic ingredients, as well as bread improvers - flour treatment agents like vitamin C (ascorbic acid) and preservatives in the commercial bakery production process [Chen et al. 2006].

It is possible to co-treat bakery and municipal wastewater to achieve the desired $\mathrm{C}: \mathrm{N}: \mathrm{P}$ ratio in order to carry out highly effective denitrification and biological phosphorus removal. The analysis of the current state of knowledge showed that 
there is a lack of data on the changes in quantitative and qualitative parameters of the municipal wastewater with a specified share of bakery wastewater during large scale treatment with an activated-sludge process. The results from fractionation of organic compounds by means of COD in this type of sewage are not available. The analysis of changes of particular fractions is also not available, making it impossible to control the purification processes in detail and obtain high efficiency of organic compounds and biogenic substance removal.

The aim of the study was to determine the effect of bakery wastewater contribution on the COD fraction changes during large scale biological wastewater treatment with the activatedsludge process. The results of the research on the effectiveness of municipal sewage treatment with a proportion of bakery wastewater and determined COD fractions can be used for: modification of the wastewater treatment process, modernization of bakery sewage pre-treatment plant, liquidation of the sewage treatment plant and discharge of bakery wastewater into the municipal sewage treatment plants.

\section{Characteristics of wastewater from bakery industry}

The bakery industry is one of the largest water users in Europe and the United States [Chen et al. 2006]. More than half of the water is discharged as wastewater. The wastewater in bakeries is primarily generated from the cleaning operations, including equipment cleaning and floor washing. It can be characterized as high loading, fluctuating flow containing oil and grease. The ratio of water consumed to products is about 10 in common food industry, much higher than that of 5 in the chemical industry and 2 in the paper and textiles industry. Normally, half of the water is used in the process, while the remainder is used for washing purposes, e.g., of equipment, floor, and containers [Chen et al. 2006]. Bakeries generate large amounts of acidic wastewater which contains flour, fat and sugar [bakerybazar.com]; they also use large amounts of butter, flour, shortening, eggs and fillings of various types. The bakery wastewater is biodegradable; hence, the biological treatment can be effective in reducing BOD. This type of wastewater is normally treated by physical and chemical processes and the various treatment possibilities are presented in Figure 1.
Large commercial bakeries producing cakes, pies, cookies, biscuits, brownies, rolls and a variety of other desserts generate wastewater with loads of contaminants which are too high for discharge to a municipal sewerage system without pretreatment. The flow diagram of bakery wastewater treatment plant is presented in Figure 2.

Pretreatment of the wastewater from the bakery industry is necessary before discharge to a municipal sewer system. The process flow diagram of the bakery wastewater pretreatment system is presented in Figure 3.

A very efficient way to accomplish this is through the installation of a Dissolved Air Flotation (DAF) system. These systems are the optimal solution for the removal of such materials as fats, oil and grease. A DAF system utilizes the gravity separation technique that uses air bubbles in the wastewater holding tank to attach to the insoluble materials and float them to the surface. Certain materials used in the baking process are heavier than water and thus require the addition of flocculants, which - when introduced - cause the materials to join in clusters light enough to float to the surface. These contaminants then accumulate on the surface of the DAF tank as sludge and are scraped off and removed from the wastewater.

Pretreatment using a DAF in commercial bakeries allows for a reduction of FOG (fats, oil and grease) by $99 \%$ and Total Suspended Solids (TSS) by $97 \%$. The requirement for flocculants as well as $\mathrm{pH}$ adjustment of the water for effective FOG removal can be fully automated [ecologixsystems.com].

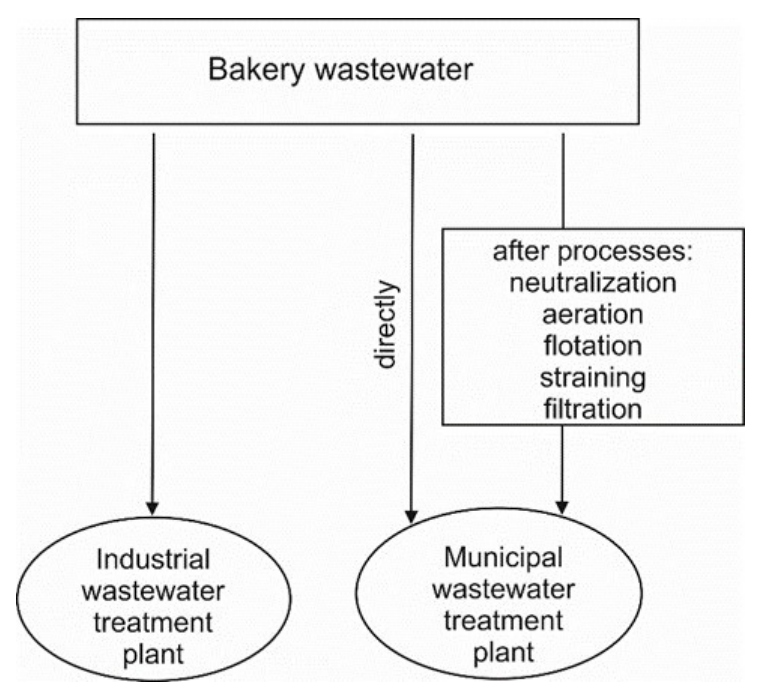

Figure 1. The possibilities of bakery wastewater treatment and co-treatment 


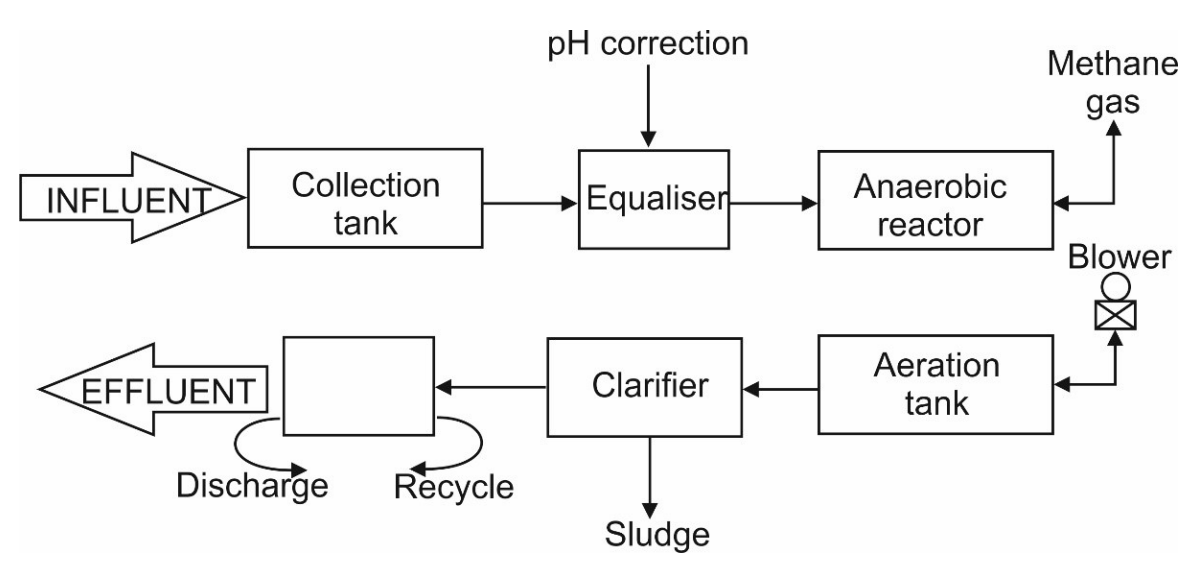

Figure 2. Flow diagram of bakery wastewater treatment plant [bakerybazar.com]

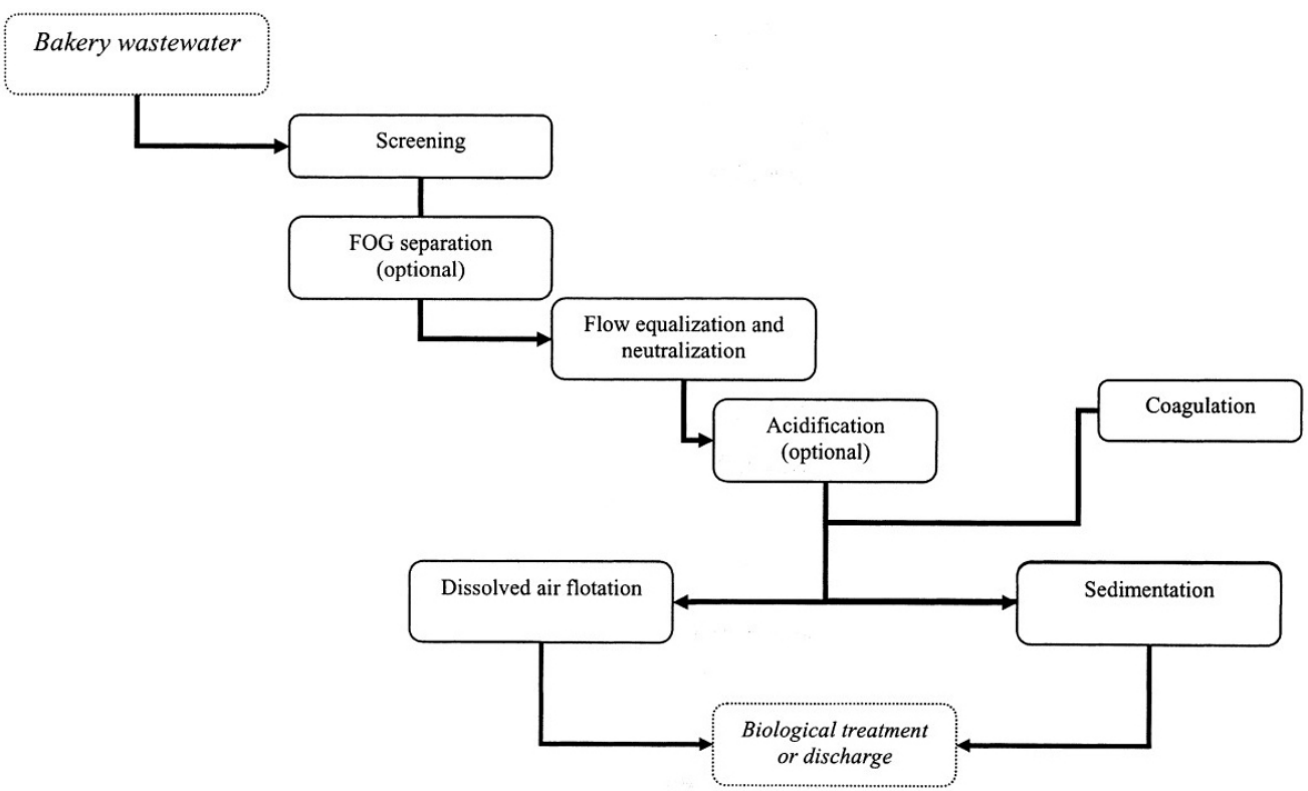

Figure 3. Bakery wastewater pretreatment system process flow diagram [Chen et al. 2006]

The bakery wastewater contains products which are made from the strains of yeast selected for their special qualities relating to the needs of the baking industry. The bakery effluent containing yeast is a major source of pollution as it has a high biological oxygen demand (BOD), high chemical oxygen demand (COD), total Kjeldahl nitrogen (TKN), dark color, and nonbiodegradable organic pollutants.

The biological treatment of wastewater eliminates important components of the organics in the wastewater. However, the biochemical decomposition by conventional treatment method may not be enough to obtain a complete color reduction. Although there is no effluent limitation set for color in the regulations, it can be necessary to use a more effective process for the reduction of color [Catalkaya and Sengul 2006].
The research on trends in the recovery of phosphorus in the bioavailable forms from wastewater has proven that other than in municipal WWTPs, struvite (a superior recovered P product in terms of plant availability) precipitation has recently been investigated in a broad variety of wastewater streams from the bakery production [Uysal et al. 2014; Melia et al. 2017].

Most bakery industries are of small or medium size, often located in densely populated areas, which makes environmental problems more critical. Nevertheless, the conventional "end-of-pipe" treatment philosophy has its restrictions in dealing with these problems, as it only addresses the result of inefficient and wasteful production processes, and should be considered only as a final option [Chen et al. 2006]. Table 1 shows level of BOD, suspended solids and fats, oils and grease in the bakery wastewater. 
Table 1. Bakery wastewater characteristics

\begin{tabular}{|c|c|c|c|c|c|c|c|c|}
\hline \multirow{3}{*}{$\begin{array}{c}\text { Parameter } \\
\mathrm{pH}\end{array}$} & \multicolumn{8}{|c|}{ Type of bakery } \\
\hline & \multicolumn{4}{|c|}{ Unspecified } & Variety & \multicolumn{2}{|c|}{ Cake } & Bread \\
\hline & & $6.0-10.0$ & $4.7-5.1$ & & 5.6 & $4.7-8.4$ & $5.0-12.3$ & $6.9-7.8$ \\
\hline COD & & 3000.0 & 7000.0 & $\begin{array}{r}7500.0 \\
-10000.0\end{array}$ & 1600.0 & & $\begin{array}{c}180.0- \\
-1500.0\end{array}$ & \\
\hline $\mathrm{BOD}_{5}$ & $\begin{array}{l}1160.0- \\
-8200.0\end{array}$ & 1000.0 & 3200.0 & $\begin{array}{l}4000.0- \\
-7000.0\end{array}$ & & $\begin{array}{l}2240.0 \\
-8500.0\end{array}$ & 119.6-807.3 & $155.0-620.0$ \\
\hline TSS & & 1500.0 & 6000.0 & & & & $\begin{array}{c}12.4- \\
-1940.0\end{array}$ & \\
\hline TP & & & 6.8 & & & & $0.3-14.7$ & \\
\hline TKN & & & 36.0 & & & & $44.4-280.0^{*}$ & \\
\hline FOG & $\begin{array}{l}1070.0- \\
-4490.0\end{array}$ & 100.0 & 820.0 & & 630.0 & $\begin{array}{c}400.0- \\
-1200.0\end{array}$ & & $60.0-68.0$ \\
\hline Ref. & [4] & [2] & [7] & [9] & [4] & [4] & [10] & [4] \\
\hline
\end{tabular}

FOG - fats, oil and grease; unit: ph -; COD, $\mathrm{BOD}_{5}-\mathrm{mgO}_{2} \cdot \mathrm{dm}^{-3}$; TSS, TP, TN, TKN, FOG - $\mathrm{mg} \cdot \mathrm{dm}^{-3}$; ${ }^{*}-\mathrm{N}_{\text {Tot }}$.

\section{Characteristic of organic compounds in wastewater based on COD fractions}

COD fractionation is one of the most significant achievements in the modeling of the activated sludge systems and an indispensable part of wastewater characteristics [Sadecka 2010]. Calculation of COD fractions enables discrimination of organic contaminants based on the particle size and susceptibility to biochemical degradation including the readily- and hardly-biodegradable substrates [Struk-Sokolowska et al. 2016]. The biodegradable fractions $\left(\mathrm{S}_{\mathrm{S}}\right.$ and $\left.\mathrm{X}_{\mathrm{S}}\right)$ are mainly important at designing the systems for the biological removal of nitrogen and phosphorus. The soluble fraction $\left(\mathrm{S}_{\mathrm{S}}\right)$ consists of the substances directly available to microorganisms. The fraction of suspensions $\left(\mathrm{X}_{\mathrm{S}}\right)$, prior to be used by microorganisms, has to be decomposed by extra-cellular enzymes. Non-biodegradable fractions $\left(\mathrm{S}_{\mathrm{I}}\right.$ and $\mathrm{X}_{\mathrm{I}}$ ) are not subject to any conversion (Fig. 4, 5). In a system for sewage treatment, the concentration of soluble fraction $\left(\mathrm{S}_{\mathrm{I}}\right)$ in the inlet is equal to that in the outlet, while the suspended fraction $\left(\mathrm{X}_{\mathrm{I}}\right)$ can remain in the system due to building into the microorganism biomass or be subject to mechanical processes [Sadecka et al. 2011, Smyk et al. 2015, Struk-Sokolowska 2016]. The percentage contribution of individual COD fractions in the municipal wastewater is shown in Figure 4.

4.1)

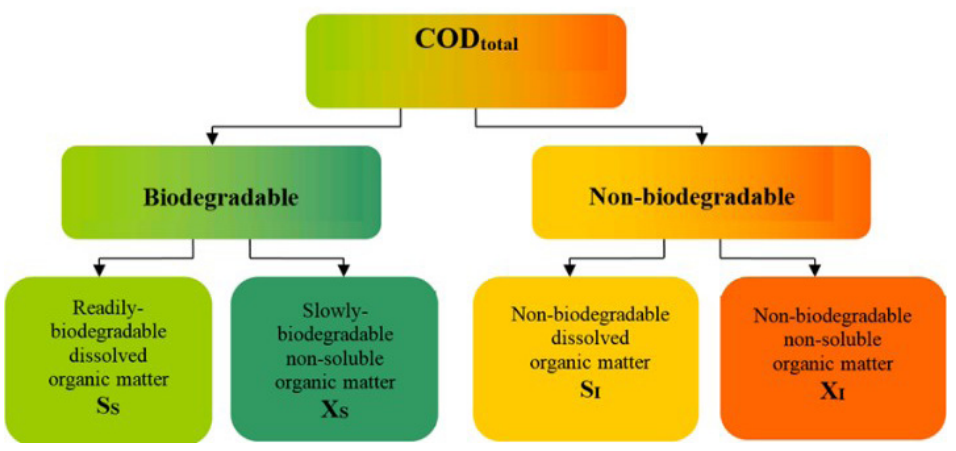

4.2)

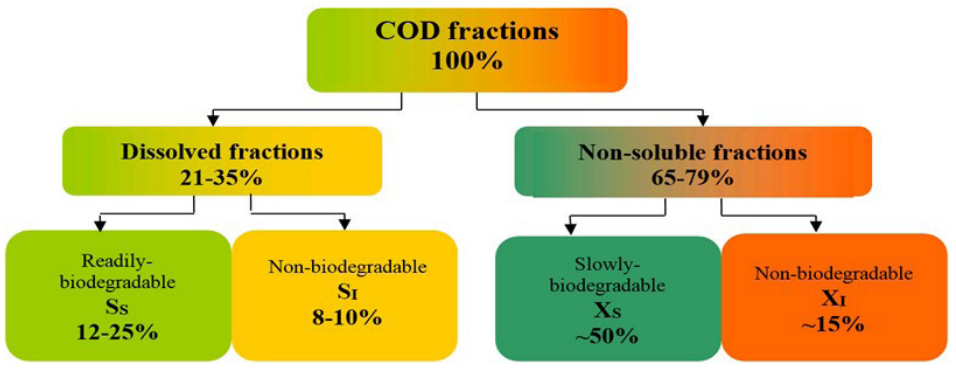

Figure 4. COD fractions and the percentage contribution of individual COD fractions in wastewater [Sadecka 2010, Fudala-Książek 2011, Płuciennik-Koropczuk 2011, Sadecka et al. 2011, Struk-Sokolowska 2015, 2016] 
RBCOD (Readily Biodegradable COD), such as volatile fatty acids, is readily degraded by microbial metabolism. SBCOD (Slowly Biodegradable COD), composed of particulate organic matter, is degraded slowly by a series of microbial actions like adsorption, hydrolysis, and metabolism (Figure 5). NBDSCOD (Non-Biodegradable Soluble COD) refractory in biodegradation is contained in industrial discharges. Aromatic compounds used in various industries are typical examples of NBDSCOD. NBDPCOD is also non-biodegradable, but is removed easily by sedimentation in a conventional WWTP [Choi et al. 2017]. A schematic diagram of the chemical oxygen demand (COD) fractions and their fates in a biological wastewater treatment plant is shown in Figure 5.

\section{MATERIALS AND METHODS}

Research methodology is presented in Figure 6. The Bakery and Confectionery Plant in Lipsk, produces rye bread, mixed bread, wheat and semi-confectionary baked dough products. The daily production is about 500 mixed breads (400 kg), 60 rye breads (48 $\mathrm{kg}$ ), 600 wheat rolls (60 kg), 300 shortbreads, doughnuts, croissants, buns and challahs $(36 \mathrm{~kg})$. Yeasts are used for the production of $80 \%$ of the portfolio and rye sourdough is used for up to $20 \%$ of all products. The bakery also uses butter, margarine, shortening as well as sugar, honey, syrup, marmalade, milk, cream, oil and eggs for their products. The wastewater from this bakery is discharged directly to the municipal wastewater treatment plant located in Lipsk.

Investigation regarding the co-treatment of municipal sewage and bakery wastewater was conducted in the wastewater treatment plant in Lipsk, Eastern Poland. In this WWTP, the volume contribution of bakery wastewater is $10 \%$ and the sewage receiver is the Biebrza River. The maximum daily flow capacity of the mechanical-biological treatment plant in Lipsk is $430 \mathrm{~m}^{3}$, the actual volume of influent wastewater in 2016 amounted to $250 \mathrm{~m}^{3} \cdot \mathrm{d}^{-1}(\mathrm{PE}=2500)$. This plant is fed with the household sewage from local town and villages. The bio-treatment process is conducted with an activated-sludge process and includes: anaerobic stage of dephosphatation, aerobic stage of organic carbon compounds oxidation and nitrification, anoxic stage of denitrification, sedimentation of activated sludge. The aerobic conditions change in the range from 0.2 to $3.0 \mathrm{gO}_{2} \cdot \mathrm{m}^{-3}$. Parameters of raw wastewater: $\mathrm{BOD}_{5} 480.0-680.0 \mathrm{mgO}_{2} \cdot \mathrm{dm}^{-3}$,

$5.1)$

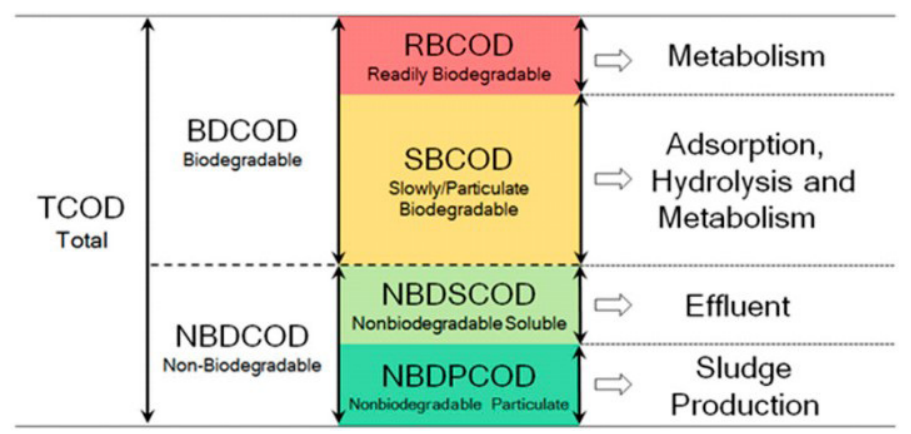

$5.2)$

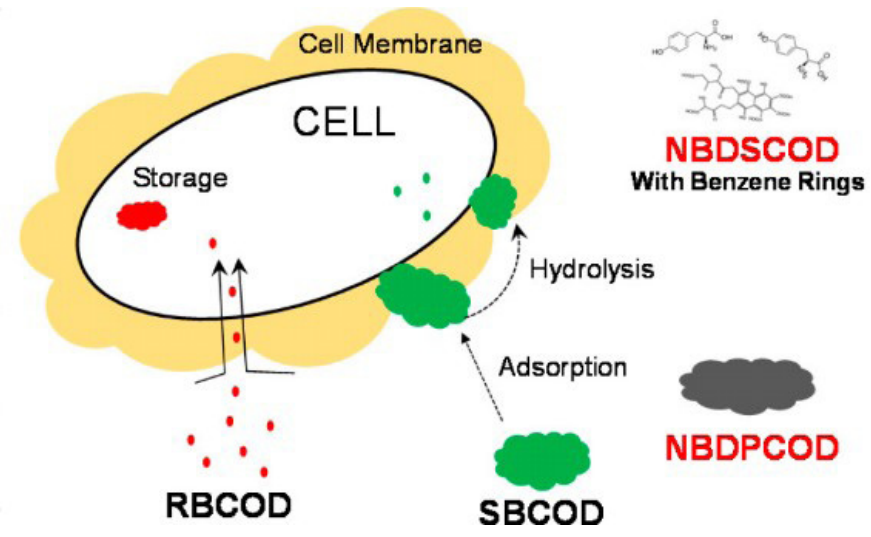

Figure 5. Schematic diagram of the chemical oxygen demand (COD) fractions and their fates in a biological wastewater treatment plant [Choi et al. 2017] 


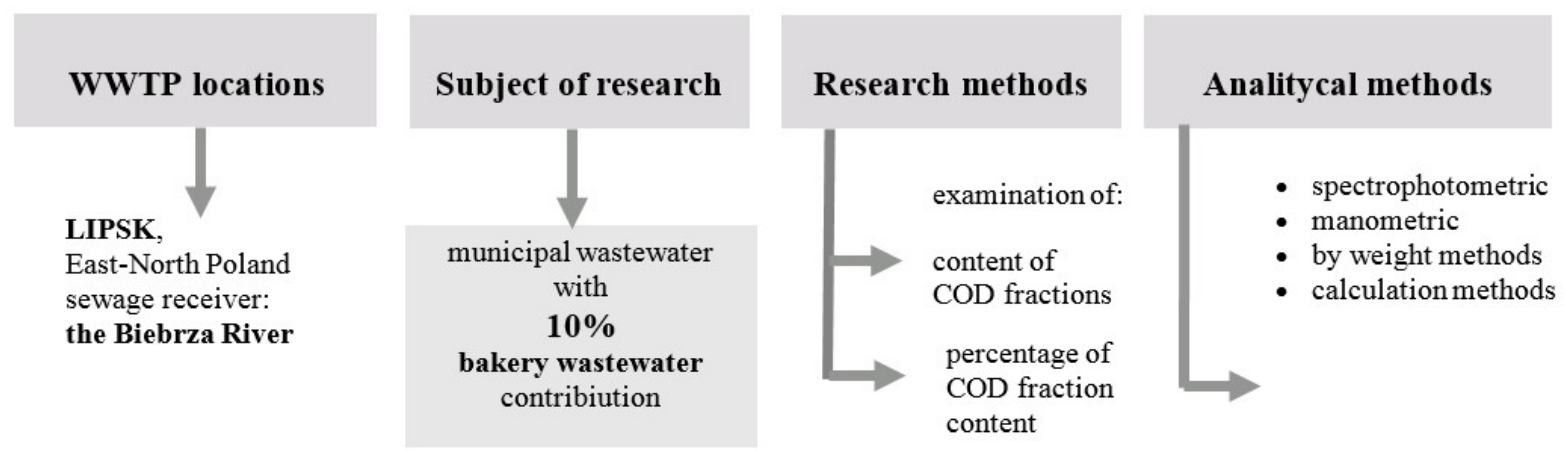

Figure 6. Research methodology

COD 626.0-998.0 $\mathrm{mgO}_{2} \cdot \mathrm{dm}^{-3}, \mathrm{pH}$ 6.4-8.3, TSS $390.0-500.0 \quad \mathrm{mg} \cdot \mathrm{dm}^{-3}$, TN $112.0-150.0$ $\mathrm{mgN} \cdot \mathrm{dm}^{-3}$, TP $24.0-48.0 \mathrm{mgP} \cdot \mathrm{dm}^{-3}$.

The samples of wastewater for physicochemical analyses were collected in July 2016. Four analytical series were conducted in the wastewater treatment plant receiving bakery wastewater. The list of process line points from which the analyzed samples of wastewater were collected is provided in Table 2.

The analytical results were used to compute the values and percentage contribution of indi- vidual COD fractions in wastewater. The method used for COD fractions determination in wastewater was developed based on the ATV 131P guidelines. The list of formulas used for calculations is provided in Table 3 .

In order to establish $\mathrm{S}_{\mathrm{COD}}$, the COD of crude wastewater was determined after centrifugation $(\mathrm{RMP}=3000 \mathrm{rpm} ; \mathrm{t}=10 \mathrm{~min})$, decantation, and filtration through a membrane filter made of glass fiber, with the pore size of $0.45 \mu \mathrm{m}$. The analysis of $\mathrm{S}_{\mathrm{I}}$ consisted of determining COD of the treated wastewater sample after centrifuga-

Table 2. List of process line points from which samples of wastewater were collected

\begin{tabular}{|c|l|c|}
\hline Sample & \multicolumn{1}{|c|}{ Treatment process stage } & Stage type \\
\hline 1 & influent & raw wastewater \\
\hline 2 & preliminary treated wastewater (after sand separator) & pre-treatment \\
\hline 3 & preliminary treated wastewater (after grit chamber) & \\
\hline 4 & wastewater collected from pumping station & anaerobic \\
\hline 5 & wastewater from chamber of dephosphatation & anoxic \\
\hline 7 & wastewater from chamber of denitrification & aerobic \\
\hline 8 & wastewater from chamber of nitrification & effluent \\
\hline
\end{tabular}

Table 3. List of formulas used for calculations

\begin{tabular}{|c|c|c|}
\hline Symbol & Formula & Name of organic matter \\
\hline $\mathrm{S}_{\mathrm{COD}}$ & $\mathrm{S}_{\mathrm{COD}}=\mathrm{S}_{\mathrm{S}}+\mathrm{S}_{\mathrm{I}}$ & dissolved organic contaminants \\
\hline $\mathrm{S}_{\mathrm{s}}$ & $\mathrm{S}_{\mathrm{S}}=\mathrm{S}_{\mathrm{COD}}-\mathrm{S}_{\mathrm{I}}$ & COD of readily-biodegradable dissolved organic matter \\
\hline $\mathrm{S}_{1}$ & $S_{1}=S_{C O D}-S_{S}$ & COD of non-biodegradable dissolved organic matter \\
\hline $\mathrm{X}_{\mathrm{s}}$ & $\mathrm{X}_{\mathrm{S}}=\mathrm{BOD}_{\mathrm{T}}-\mathrm{S}_{\mathrm{S}}$ & COD of slowly biodegradable insoluble organic matter \\
\hline$X_{1}$ & $\begin{array}{l}X_{1}=A \cdot X_{C O D} \\
X_{1}=X_{C O D}-X_{S}\end{array}$ & COD of non-biodegradable insoluble organic matter \\
\hline $\mathrm{BOD}_{\mathrm{T}}$ & $\mathrm{BOD}_{\mathrm{T}}=\mathrm{BOD}_{5} / 0,6$ & total biochemical oxygen demand \\
\hline $\mathrm{BOD}_{\mathrm{t}}$ & $\mathrm{BOD}_{\mathrm{t}}=\mathrm{BOD}_{\mathrm{T}} \cdot\left(1-10^{-k \cdot t}\right)$ & BOD after time $t$ \\
\hline $\mathrm{X}_{\mathrm{COD}}$ & $\begin{array}{l}X_{C O D}=X_{S}+X_{1} \\
X_{C O D}=X_{S} / 0.75\end{array}$ & total concentration of molecular organic matter \\
\hline
\end{tabular}

A - coefficient ranged from 0.2 to 0.35 , depending on the type of wastewater or relatively on wastewater retention time in the primary settling tank; A was assumed at $\mathrm{A}=0.25$.

The obtained values of $\mathrm{S}_{\mathrm{S}}, \mathrm{S}_{\mathrm{I}}, \mathrm{X}_{\mathrm{S}}, \mathrm{X}_{\mathrm{I}}$, and total COD enabled the calculation of individual COD fractions percentage. 
tion, decantation, and filtration. The total BOD was computed based on experimentally established $\mathrm{BOD}_{5}$ of wastewater. The values of kinetics of the first phase of BOD, described with the first order reaction equation, $\mathrm{k}$ - reaction rate constant; for the substances contained in the household wastewater range from 0.1 to $0.3 \mathrm{~d}^{-1}$, and the mean value is assumed at $0.23 \mathrm{~d}^{-1}$. The total concentration of molecular organic matter was determined based on a dependency provided in the ATV-131 guidelines.

\section{RESULTS}

The values and percentage of COD fractions after subsequent steps of treatment in WWTP in Lipsk are shown in Table 4. The average values and percentage of COD fractions after subsequent steps of treatment in dependence of total COD are shown in Table 5.

In addition to the amount of organic compounds belonging to COD fraction, the proportions between fractions also are relevant to the wastewater treatment technologies. The organic compounds determined by the biodegradable fractions $\left(\mathrm{S}_{\mathrm{S}} ; \mathrm{X}_{\mathrm{S}}\right)$, will be used with the highest efficiency during the mechanical and biological wastewater treatment, while the organic compounds concentration expressed by hardly or nonbiodegradable fractions is subject to the smallest variation. As a result, the percentage of fractions in total COD is changed.

\section{DISCUSSION}

The percentage of individual COD fractions in the municipal wastewater with bakery wastewater contribution was compared with the COD fractions shares in the wastewater from other industries (dairy, olive mill, tomato, sugar beet, potato processing, winery, paper mill) presented in literature [Rodriguez et al. 2007, Chiavola et al. 2014, Struk-Sokolowska 2014, 2015, Choi et al. 2017]. The comparison of the COD fractions in raw industrial or municipal wastewater with industrial sewage contribution and split per industry is shown in Table 6.

Comparing the percentage of individual COD fractions in municipal wastewater with $10 \%$ bakery wastewater contribution to the shares in municipal wastewater with $10 \%$ dairy wastewater contribution [Struk-Sokolowska 2014, 2015] proves close similarities. It may therefore be assumed that the co-treatment of bakery and municipal wastewater will occur with high efficiency using a technology which is well recognized and described in literature i.e. a sequencing batch reactor (SBR).

The research carried out in Italy by Chiavola et al. [2014] shows that the share of biodegradable organic matter in the sewage from olive mill was $66.6 \%$, out of which the dissolved $\mathrm{S}_{\mathrm{S}}=29.2 \%$, and non-soluble $\mathrm{X}_{\mathrm{S}}=37.4 \%$, while non-biodegradable organic matter was $33.4 \%$, including dissolved $\mathrm{S}_{\mathrm{I}}=9.9 \%$ and non-soluble $\mathrm{X}_{\mathrm{I}}=23.5 \%$. The municipal sewage with bak-

Table 4. Values and percentage of COD fractions after subsequent steps of treatment

\begin{tabular}{|c|c|c|c|c|c|}
\hline \multirow{2}{*}{ Sample } & \multirow{2}{*}{ Unit } & \multicolumn{4}{|c|}{ COD fractions } \\
\cline { 2 - 5 } & & $\mathrm{S}_{\mathrm{S}}$ & $\mathrm{S}_{\mathrm{I}}$ & $\mathrm{X}_{\mathrm{s}}$ & $\mathrm{X}_{\mathrm{I}}$ \\
\hline \multirow{2}{*}{1} & $\mathrm{mgO}_{2} \cdot \mathrm{dm}^{-3}$ & $368.9-411.3$ & $18.7-28.1$ & $355.4-564.4$ & $118.5-188.1$ \\
& $\%$ & $32.1-45.5$ & $2.1-2.4$ & $39.3-49.1$ & $13.1-16.4$ \\
\hline \multirow{2}{*}{2} & $\mathrm{mgO}_{2} \cdot \mathrm{dm}^{-3}$ & $427.3-453.9$ & $18.7-28.1$ & $206.0-679.4$ & $68.7-226.5$ \\
& $\%$ & $32.7-59.3$ & $2.0-2.6$ & $28.6-49.0$ & $9.5-16.3$ \\
\hline \multirow{2}{*}{3} & $\mathrm{mgO}_{2} \cdot \mathrm{dm}^{-3}$ & $392.9-643.3$ & $18.7-28.1$ & $123.4-507.1$ & $41.1-169.0$ \\
& $\%$ & $35.8-77.8$ & $2.3-2.6$ & $14.9-46.2$ & $5.0-15.4$ \\
\hline \multirow{2}{*}{4} & $\mathrm{mgO}_{2} \cdot \mathrm{dm}^{-3}$ & $103.3-276.9$ & $18.7-28.1$ & $46.7-423.1$ & $15.6-141.0$ \\
& $\%$ & $31.9-56.0$ & $3.2-10.1$ & $25.3-48.7$ & $8.5-16.2$ \\
\hline \multirow{2}{*}{5} & $\mathrm{mgO}_{2} \cdot \mathrm{dm}^{-3}$ & $8.9-52.3$ & $18.7-28.1$ & $11.0-71.1$ & $3.7-23.7$ \\
& $\%$ & $6.8-61.0$ & $21.3-21.8$ & $12.8-53.9$ & $4.3-18.0$ \\
\hline \multirow{2}{*}{6} & $\mathrm{mgO}_{2} \cdot \mathrm{dm}^{-3}$ & $6.9-23.3$ & $18.7-28.1$ & $33.1-33.4$ & $11.0-11.1$ \\
& $\%$ & $8.7-26.9$ & $21.6-35.5$ & $38.6-41.8$ & $12.8-13.9$ \\
\hline \multirow{2}{*}{7} & $\mathrm{mgO}_{2} \cdot \mathrm{dm}^{-3}$ & $4.9-21.3$ & $18.7-28.1$ & $11.8-37.0$ & $3.9-12.3$ \\
& $\%$ & $10.1-23.8$ & $20.9-57.7$ & $24.2-41.4$ & $8.0-13.8$ \\
\hline \multirow{2}{*}{8} & $\mathrm{mgO}_{2} \cdot \mathrm{dm}^{-3}$ & $<0.1$ & $18.7-28.1$ & $20.0-28.3$ & $6.7-9.4$ \\
& $\%$ & $<0.1$ & $33.2-51.3$ & $36.5-50.2$ & $12.2-16.7$ \\
\hline
\end{tabular}


Table 5. The average values and percentage of COD fractions after subsequent steps of treatment in dependence of total COD

\begin{tabular}{|c|c|c|c|c|c|c|}
\hline \multirow{2}{*}{ Sample } & \multirow{2}{*}{ Unit } & \multicolumn{4}{|c|}{ COD fractions } & \multirow{2}{*}{$\begin{array}{l}\text { total COD } \\
\mathrm{mgO}_{2} \cdot \mathrm{dm}^{-3}\end{array}$} \\
\hline & & $\mathrm{S}_{\mathrm{S}}$ & $S_{1}$ & $x_{S}$ & $x_{1}$ & \\
\hline 1 & $\begin{array}{c}\mathrm{mgO}_{2} \cdot \mathrm{dm}^{-3} \\
\%\end{array}$ & $\begin{array}{c}390.1 \\
38.8\end{array}$ & $\begin{array}{c}23.4 \\
2.3\end{array}$ & $\begin{array}{c}459.9 \\
44.2 \\
\end{array}$ & $\begin{array}{c}153.3 \\
14.8\end{array}$ & 903.9-1149.5 \\
\hline 2 & $\begin{array}{c}\mathrm{mgO}_{2} \cdot \mathrm{dm}^{-3} \\
\%\end{array}$ & $\begin{array}{c}440.6 \\
46.0\end{array}$ & $\begin{array}{c}23.4 \\
2.3 \\
\end{array}$ & $\begin{array}{c}442.7 \\
38.8 \\
\end{array}$ & $\begin{array}{c}105.1 \\
12.9 \\
\end{array}$ & $720.7-1387.9$ \\
\hline 3 & $\begin{array}{c}\mathrm{mgO}_{2} \cdot \mathrm{dm}^{-3} \\
\%\end{array}$ & $\begin{array}{c}518.1 \\
56.8\end{array}$ & $\begin{array}{c}23.4 \\
2.5\end{array}$ & $\begin{array}{c}315.3 \\
30.6 \\
\end{array}$ & $\begin{array}{c}105.1 \\
10.2 \\
\end{array}$ & 826.5-1097.1 \\
\hline 4 & $\begin{array}{c}\mathrm{mgO}_{2} \cdot \mathrm{dm}^{-3} \\
\%\end{array}$ & $\begin{array}{c}190.1 \\
44.0\end{array}$ & $\begin{array}{c}23.4 \\
6.7 \\
\end{array}$ & $\begin{array}{c}234.9 \\
37.0 \\
\end{array}$ & $\begin{array}{l}78.3 \\
12.4 \\
\end{array}$ & 184.3-869.1 \\
\hline 5 & $\begin{array}{c}\mathrm{mgO}_{2} \cdot \mathrm{dm}^{-3} \\
\%\end{array}$ & $\begin{array}{l}30.6 \\
33.9\end{array}$ & $\begin{array}{l}23.4 \\
21.6 \\
\end{array}$ & $\begin{array}{l}41.1 \\
33.4 \\
\end{array}$ & $\begin{array}{l}13.7 \\
11.2 \\
\end{array}$ & 85.7-131.8 \\
\hline 6 & $\begin{array}{c}\mathrm{mgO}_{2} \cdot \mathrm{dm}^{-3} \\
\%\end{array}$ & $\begin{array}{l}15.1 \\
17.8 \\
\end{array}$ & $\begin{array}{l}23.4 \\
28.6 \\
\end{array}$ & $\begin{array}{l}33.3 \\
40.2 \\
\end{array}$ & $\begin{array}{l}11.1 \\
13.4 \\
\end{array}$ & $86.5-79.1$ \\
\hline 7 & $\begin{array}{c}\mathrm{mgO}_{2} \cdot \mathrm{dm}^{-3} \\
\%\end{array}$ & $\begin{array}{l}13.1 \\
17.0 \\
\end{array}$ & $\begin{array}{l}23.4 \\
39.3 \\
\end{array}$ & $\begin{array}{l}24.4 \\
32.8 \\
\end{array}$ & $\begin{array}{c}8.1 \\
10.9 \\
\end{array}$ & 48.7-89.3 \\
\hline 8 & $\begin{array}{c}\mathrm{mgO}_{2} \cdot \mathrm{dm}^{-3} \\
\%\end{array}$ & $\begin{array}{l}<0.1 \\
<0.1\end{array}$ & $\begin{array}{l}23.4 \\
42.3 \\
\end{array}$ & $\begin{array}{l}24.2 \\
43.4 \\
\end{array}$ & $\begin{array}{c}8.1 \\
14.5 \\
\end{array}$ & $54.8-56.4$ \\
\hline
\end{tabular}

Table 6. Comparison of the COD fractions in raw industrial or municipal wastewater (with industrial sewage contribution) depending on the industry

\begin{tabular}{|c|c|c|c|c|c|c|}
\hline \multirow{2}{*}{ Industry } & \multicolumn{4}{|c|}{ COD fractions, $\%$} & \multirow{2}{*}{$\begin{array}{c}\mathrm{COD}_{\text {tot' }} \\
\mathrm{mgO}_{2} \cdot \mathrm{dm}^{-3}\end{array}$} & \multirow{2}{*}{ Reference } \\
\hline & $\mathrm{S}_{\mathrm{S}}$ & $x_{S}$ & $\mathrm{~S}_{1}$ & $x_{1}$ & & \\
\hline Bakery $(10 \%)$ & 38.8 & 44.2 & 2.3 & 14.8 & 626.0-998.0 & this paper \\
\hline Dairy $(10 \%)$ & 32.5 & 47.8 & 2.7 & 17.0 & 863.7 & Struk-Sokolowska, 2014 \\
\hline Dairy $(10 \%)$ & 38.8 & 45.5 & 1.0 & 15.2 & 1079.0 & Struk-Sokolowska, 2015 \\
\hline Olive mill & 29.2 & 37.4 & 9.9 & 23.5 & 60000.0 & Chiavola et al., 2014 \\
\hline Tomato processing & * & * & \multicolumn{2}{|c|}{$* * 18.4$} & * & Rodriguez et al., 2007 \\
\hline Sugar beet processing & * & * & \multicolumn{2}{|c|}{ **18.9 } & * & Rodriguez et al., 2007 \\
\hline Potato processing & * & * & \multicolumn{2}{|c|}{$* * 28.8$} & * & Rodriguez et al., 2007 \\
\hline Winery & * & * & \multicolumn{2}{|c|}{$* * 20.9$} & * & Rodriguez et al., 2007 \\
\hline Paper mill $(25 \%)$ & 4.2 & 43.1 & 39.5 & 13.2 & 110.7 & Choi et al., 2017 \\
\hline Paper mill (75\%) & 0.6 & 34.0 & 59.8 & 5.5 & 112.0 & Choi et al., 2017 \\
\hline
\end{tabular}

* - no data available; ${ }^{* *}$ - sum of fractions $S_{1}$ and $X_{1}$

ery wastewater contribution has a higher share of biodegradable organic matter $\left(\mathrm{S}_{\mathrm{S}}\right.$ and $\left.\mathrm{X}_{\mathrm{S}}\right)$, with smaller share of non-biodegradable (inert) fraction $\mathrm{S}_{\mathrm{I}}$ and $\mathrm{X}_{\mathrm{I}}$, and is highly susceptible to biological treatment processes.

In the research presented by Rodriguez et al. [2007] the share of non-biodegradable (inert) fractions $\mathrm{S}_{\mathrm{I}}$ and $\mathrm{X}_{\mathrm{I}}$ in wastewater from tomato, sugar beet, potato and winery processing were $18.4,18.9,28.8$ and $20.9 \%$, respectively. In the municipal wastewater with $10 \%$ bakery wastewater, the contribution shares of non-biodegradable organic matter (as a sum of fractions $\mathrm{S}_{\mathrm{I}}$ and $\mathrm{X}_{\mathrm{I}}$ ) were lower and amounted to $17.1 \%$.

The research conducted by Chen et al. [2017] proved that the municipal wastewater with 25 or $75 \%$ contribution of paper mill sewage is char- acterized by a different composition. The biggest differences were attributed to biodegradable dissolved organic matter $\left(\mathrm{S}_{\mathrm{S}}\right.$ faction) levels. In the municipal wastewater containing sewage from the paper mill, the $\left(\mathrm{S}_{\mathrm{S}}\right)$ fraction was 4.2 or $0.6 \%$, whereas in the municipal wastewater with bakery wastewater, it was up to $38.8 \%$. This confirms that the wastewater from the paper mill is definitely less susceptible to the biological treatment.

\section{CONCLUSIONS}

1. The bakery sewage from small and mediumsized bakeries can be discharged to the municipal wastewater treatment plant and treated there successfully. The presence of bakery 
wastewater in a stream of municipal sewage does not cause operational problems at the facility but positively influences the biodegradable organic matter formation.

2. The results indicated that the municipal wastewater containing bakery sewage is susceptible to biological degradation as evidenced by the ratio of $\mathrm{COD} / \mathrm{BOD}_{5}<1.4$.

3. In the raw municipal wastewater with bakery sewage contribution, the dominant percentage was recorded for the fractions of biodegradable contaminants $\left(\mathrm{S}_{\mathrm{S}}\right.$ and $\left.\mathrm{X}_{\mathrm{S}}\right)$ reaching about $83 \%$ of the total COD of sewage.

4. During the full-scale biological wastewater treatment with an activated-sludge process, the amount of readily-biodegradable dissolved organic matter $\left(\mathrm{S}_{\mathrm{S}}\right)$ and slowly-biodegradable non-soluble organic matter $\left(\mathrm{X}_{\mathrm{S}}\right)$ decreased, which confirms high treatment efficiency.

5. During the pre-treatment (sand separator, grit chamber), a decrease of slowly-biodegradable non-soluble organic matter $\left(\mathrm{X}_{\mathrm{S}}\right)$ was observed, which confirms the high efficiency of mechanical treatment.

6. The highest decrease of readily-biodegradable dissolved organic matter $\left(\mathrm{S}_{\mathrm{S}}\right)$ was noted in the wastewater from dephosphatation and denitrification chambers.

7. A dose of bakery wastewater significantly raised the denitrification capacity at the WWTP, because of the significant increase of readily-biodegradable wastewater substrates.

8. Low value of non-biodegradable non-soluble organic matter $\left(\mathrm{X}_{\mathrm{I}}\right)$ in the effluent indicates a high efficiency of sedimentation in the secondary settling tank.

\section{Acknowledgments}

The research has been carried out in the framework of project No. S/WBiIS/3/2014 and financed from the funds for science MNiSW.

\section{REFERENCES}

1. ATV-DVWK-A131P 2000. Dimensioning of single stage activated sludge plant. WA rules and standards - German Association for Water. Attachment: COD balance sheet, Seidel-Przywecki (in Polish).
2. Bakery Industry, Wastewater treatment in bakeries, http://www.bakerybazar.com/2009/10/waste-watertreatment-in-bakeries_05.html, access: 17.01.2018.

3. Catalkaya E.C., Sengul F. 2006. Application of Box-Wilson experimental design method for the photodegradation of bakery's yeast industry with $\mathrm{UV} / \mathrm{H} 2 \mathrm{O} 2$ and $\mathrm{UV} / \mathrm{H} 2 \mathrm{O} 2 / \mathrm{Fe}(\mathrm{II})$ process, Journal of Hazardous Materials B128, 201-207.

4. Chen J. P., Yang L., Bai R., Hung Y. T. 2006. Bakery Waste Treatment. Taylor\&Francis Group. LLC.

5. Chiavola A., Farabegoli G., Antonetti F. 2014. Biological treatment of olive mill wastewater in a sequencing batch reactor. Biochem. Engi. Journ., 85, 71-78.

6. Choi Y-T., Beak S-R., Kim J-I., Choi J-W., Hur J., Lee T-U., Park C-J., Lee B. J. 2017. Characteristics and Biodegradability of Wastewater Organic Matter in Municipal Wastewater Treatment Plants Collecting Domestic Wastewater and Industrial Discharge, Water, 9, 409.

7. Ecologix Environmental Systems, Commercial Bakery Wastewater Treatment, http:/www. ecologixsystems.com/industry-bakery.php, access: 17.01.2018.

8. Fudala-Ksiazek S. 2011. The impact of the discharge of landfill leachate on the efficiency of municipal wastewater treatment plant. PhD thesis, Gdansk University of Technology (in Polish).

9. Gąsiorowski H. 2004. Wastewater treatment for bakeries and confectionary plants. Przegląd Piekarski i Cukierniczy, 03/2004 (in Polish).

10. Krzanowski S., Wałęga A., Paśmionka I. 2008. Treatment of sewage from selected food manufacturing plants, Infrastructure and Ecology of Rural Areas, Polish Academy of Science, Kracow.

11. Melia P. M., Cundy A. B., Sohi S. P., Hooda P. S., Busquets R. 2017. Trends in the recovery of phosphorus in bioavailable forms from wastewater, Chemosphere, 186, 381-395.

12. Orhon D., Babuna F. G., Karahan O. 2009. Industrial Wastewater Treatment by Activated Sludge, IWA Publishing.

13. Płuciennik-Koropczuk E. 2011. COD fractions as a measure of the quality of wastewater. $\mathrm{PhD}$ thesis, University of Zielona Góra, (in Polish).

14. Rodriguez L., Villasenor J., Fernandez F. J. 2007. Use of agro-food wastewater for the optimisation of the denitrification process. Wat. Scie. Tech., 55, $10,63-70$.

15. Sadecka Z. 2010. Fundamentals of biological wastewater treatment, Warsaw, Wyd. Seidel-Przywecki (in Polish).

16. Sadecka Z., Płuciennik-Koropczuk E. 2010. COD fractions in kinematic models. In: Wastewater treatment and sludge treatment. Zielona Gora, Printing House of University of Zielona Góra, 39-48. 
17. Sadecka Z., Płuciennik-Koropczuk E., Sieciechowicz A. 2011. COD fractions in wastewater kinematic models. Forum Eksploatatora, 54(3), 72-77 (in Polish).

18. Smyk J., Ignatowicz K., Struk-Sokolowska J. 2015. COD fractions changes during sewage treatment with constructed wetland, Journal of Ecological Engineering, 16(3), 43-48.

19. Struk-Sokołowska J. 2014. Speciation of organic matter by COD in wastewater on the chosen example. Interdysc. Zagadn. w Inż. i Ochr. Środ., Ofic. Wydawn. Pol. Wroc., 4, 807-820 (in Polish).

20. Struk-Sokolowska J. 2015. COD fraction changes in the process of municipal and dairy wastewater treatment in SBR reactors. PhD thesis, Bialystok University of Technology (in Polish).

21. Struk-Sokolowska J., Wiater J., Rodziewicz J. 2016. Wastewater organic compounds characterization on the basis of COD fractions. Gaz, Woda $i$ Technika Sanitarna, 1(3), 14-20 (in Polish).

22. Uysal A., Demir S., Sayilgan E., Eraslan F., Kucukyumuk Z. 2014. Optimization of struvite fertilizer formation from baker's yeast wastewater: growth and nutrition of maize and tomato plants, Environ. Sci. Pollut. Res. 21, 3264-3274. 